\title{
PERBANDINGAN PENGUKURAN RADIOMETER DAN RADIOSONDE PADA MUSIM HUJAN DI DRAMAGA BOGOR
}

\author{
A Comparison between Radiometer and Radiosonde Measurements \\ During the Rainy Season in Dramaga Bogor
}

\author{
Ibnu Athoillah ${ }^{1)^{\star}}$, Saraswati Dewi' ${ }^{2)}$, Findy Renggono ${ }^{3)}$ \\ ${ }^{1,2,3)}$ Balai Besar Teknologi Modifikasi Cuaca - Badan Pengkajian dan Penerapan Teknologi, Gedung Ir. \\ Mohammad Soebagio, GEOSTECH (820), Kawasan PUSPIPTEK, Serpong, Tangerang Selatan \\ *E-mail : ibnu.athoillah@bppt.go.id
}

\begin{abstract}
Intisari
Balai Besar Teknologi Modifikasi Cuaca (BB-TMC) BPPT bekerjasama dengan Badan Meteorologi Klimatologi dan Geofisika (BMKG) melakukan kegiatan Intensive Observation Period (IOP) selama puncak musim hujan pada tanggal 18 Januari - 16 Februari 2016 di wilayah Jabodetabek. Salah satu peralatan yang digunakan untuk observasi adalah Radiometer dan Radiosonde. Pada penelitian ini akan difokuskan bagaimana perbandingan hasil dari pengukuran Radiometer dan Radiosonde selama kegiatan IOP terutama untuk parameter temperatur dan kelembapan relatif. Hasil dari perbandingan pada profil atmosfer di lapisan tertentu terlihat adanya data yang mempunyai kecenderungan jauh dan tidak memiliki kedekatan nilai. Untuk pengukuran temperatur dengan radiometer jika dibandingkan dengan radiosonde, korelasi data semakin kecil di lapisan atas, sebaliknya jika untuk pengukuran kelembapan relatif, korelasi data di lapisan atas lebih tinggi daripada korelasi data di lapisan bawah. Sedangkan jika dibandingkan pada satu waktu antara radiometer dan radiosonde menunjukkan kecocokan untuk kedua data, meskipun kecocokan data kelembapan relatif lebih kecil dibandingkan data temperatur.
\end{abstract}

Kata Kunci : Radiometer, Radiosonde, Temperatur, Kelembapan Relatif.

\begin{abstract}
National Laboratory for Weather Modification (BB-TMC) BPPT has colaborated with Meteorological Climatology and Geophysic Agency (BMKG) in conducting Intensive Observation Period (IOP) during the peak of rainy season in Jabodetabek area on January $18^{\text {th }}$ - February $16^{\text {th }} 2016$. One of the tools used in the observation is Radiometer and Radiosonde. This study will focus on comparison result between Radiometer and Radiosonde measurement during IOP especially for temperature and relative humidity parameters. The result in a particular layer of profile atmosphere indicates that the data tends to deviate away. The temperature difference measured using radiometer and radiosonde in the upper layer shows smaller value than that in the lower layer. In contrast, the correlation for relative humidity data in the upper layers is higher than in the lower layers. Meanwhile when compared at one time indicate a good match for both data, although the data matches of the relative humidity are lower than the temperature data.
\end{abstract}

Keywords : Radiometer, Radiosonde, Temperature, Relative Humidity.

\section{PENDAHULUAN}

Kegiatan pengamatan atmosfer secara intensif atau yang lebih dikenal dengan Intensive Observation Period (IOP) dilakukan oleh Balai Besar Teknologi Modifikasi Cuaca (BBTMC) Badan Pengkajian dan Penerapan Teknologi bekerja sama dengan Badan Meteorologi Klimatologi dan Geofisika (BMKG) guna memahami kondisi cuaca secara detail dalam rentang waktu terjadinya curah hujan tinggi di wilayah Jabodetabek.

Kegiatan IOP ini dilaksanakan pada 18 Januari - 16 Februari 2016 di dua lokasi pengamatan yaitu di Stasiun Klimatologi BMKG Dramaga Bogor dan Gedung BBTMC di kawasan PUSPIPTEK Serpong. Dalam kegiatan ini, pengamatan dan pengukuran parameter cuaca dilakukan selama 24 jam dengan menggunakan berbagai instrumen diantaranya adalah Radiometer dan Radiosonde. Kedua instrumen tersebut dapat melakukan pengukuran temperatur, kelembapan relatif, dan kandungan uap air secara vertikal dan kontinu dengan resolusi temporal yang cukup tinggi.

Pengukuran dengan balon radiosonde selama ini memiliki keterbatasan waktu yaitu pengukuran dilakukan pada jam-jam tertentu saja 
sedangkan pengukuran dengan radiometer dapat dilakukan secara kontinyu tiap menit (Mattioli et al., 2008; Chan, 2009).

Madhulatha et al. (2013) menyatakan bahwa Microwave Radiometer (MWR) dapat menggambarkan kecocokan profil suhu dan kerapatan uap air yang cukup baik dengan radiosonde GPS. Setidaknya, ada 15 parameter termodinamika yang berasal dari data MWR yang berkorelasi signifikan (signifikan secara statistik) dengan parameter yang berasal dari pengamatan radiosonde GPS.

Dalam penelitian ini akan dilakukan perbandingan dari hasil pengukuran Radiometer dan Radiosonde selama periode pengamatan.

\subsection{Radiometer MP-3000}

Metode untuk mengambil profil suhu, kelembapan, dan awan dapat dilakukan menggunakan pengamatan dari radiometer (Hewison, 2007). Radiometer MP-3000 dari Radiometrics merupakan microwave radiometer yang dirancang untuk mengukur suhu, kelembapan relatif, dan kandungan uap air di troposfer bawah. Proses konvektif mempunyai peranan penting dalam struktur termodinamika atmosfer terutama di daerah tropis dan sering dikaitkan dengan awan dan curah hujan (Ratnam et al., 2013). Jangkauan ketinggian untuk pengukuran radiometer ini dari permukaan mencapai ketinggian $10 \mathrm{~km}$ dan menghasilkan profil suhu, kelembapan relatif, dan kandungan uap air dengan resolusi tinggi..

Pengukuran dengan Radiometer ini ditempatkan dan dioperasikan di Stasiun Klimatologi Dramaga Bogor dari tanggal 18 Januari - 16 Februari 2016. Pengoperasian radiometer ini dilakukan selama 24 jam selama periode pengamatan.

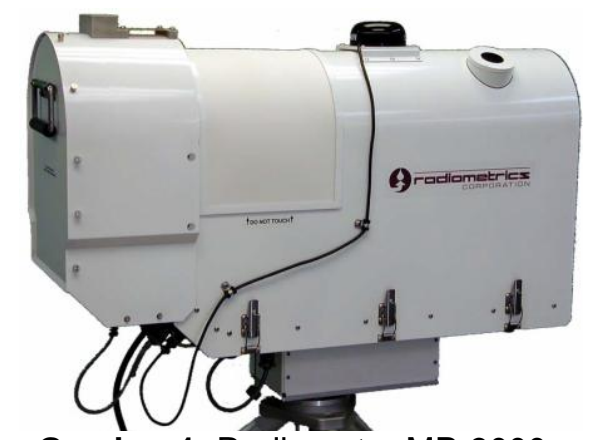

Gambar 1. Radiometer MP-3000.

Sistem sensor pengukur terdapat dalam suatu box yang dipasang pada tripod. Sistem ini juga mencakup sensor untuk tekanan atmosfer dan sensor hujan. Spesifikasi dari radiometer MP-3000 disajikan pada Tabel 1.

Tabel 1. Spesifikasi Radiometer MP-3000.

\begin{tabular}{|c|c|}
\hline Parameter & Spesifikasi \\
\hline $\begin{array}{lll}\text { Calibrated } & \text { Brightness } & \text { Temperature } \\
\text { Accuracy } & & \\
\end{array}$ & $0.2+0.002^{*} \mid$ TkBB-Tsky| \\
\hline Long Term Stability & $<1.0 \mathrm{~K} / \mathrm{yr}$ typical \\
\hline Resolution (depends on integration time) & 0.1 to $1 \mathrm{~K}$ \\
\hline Brightness Temperature Range & $0-400 \mathrm{~K}$ \\
\hline $\begin{array}{l}\text { Antenna System Optical Resolution and } \\
\text { Side Lobes } \\
22-30 \mathrm{GHz} \\
51-59 \mathrm{GHz} \\
170-184 \mathrm{GHz}\end{array}$ & $\begin{array}{ll}4.9-6.3^{\circ} & -24 \mathrm{~dB} \\
2.4-2.5^{\circ} & -27 \mathrm{~dB} \\
1.0^{\circ}-1.1^{\circ} & -40 \mathrm{~dB}\end{array}$ \\
\hline $\begin{array}{l}\text { Integration Time (user selectable in } 10 \\
\text { msec increments) }\end{array}$ & 0.01 to 2.5 seconds \\
\hline $\begin{array}{l}\text { Frequency Agile Tuning Range (Accuracy = } \\
\left. \pm 3^{*} 10-6\right) \\
\text { Low Water Vapor Band (MP-1500A \& MP- } \\
3000 \mathrm{~A}) \\
\text { Oxygen Band (MP-2500A \& MP-3000A) } \\
\text { Minimum Frequency step size (K, V and } \\
\text { 183) }\end{array}$ & 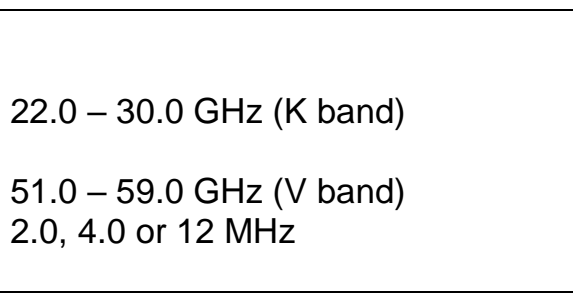 \\
\hline $\begin{array}{l}\text { Standard calibrated channels } \\
\text { MP-3000A }\end{array}$ & 35 \\
\hline $\begin{array}{l}\text { Pre-detection channel bandwidth (effective } \\
\text { double-sided RF bandwidth) }\end{array}$ & $300 \mathrm{MHz}$ (except MP183A = $1 \mathrm{GHz})$ \\
\hline $\begin{array}{l}\text { Surface Sensor Accuracy } \\
\text { Temperature }\left(-50^{\circ} \text { to }+50^{\circ} \mathrm{C}\right) \\
\text { Relative Humidity }(0-100 \%) \\
\text { Barometric pressure }(800 \text { to } 1060 \mathrm{mb}) \\
\text { IRT (Note: } \Delta \mathrm{T}=\text { Tambient - Tcloud) }\end{array}$ & $\begin{array}{l}0.5^{\circ} \mathrm{C} @ 25^{\circ} \mathrm{C} \\
2 \% \\
0.3 \mathrm{mb} \\
\left(0.5+.007^{*} \Delta \mathrm{T}\right)^{\circ}, \mathrm{C}\end{array}$ \\
\hline $\begin{array}{l}\text { Brightness Temperature algorithm for level1 } \\
\text { products }\end{array}$ & 4 point nonlinear model \\
\hline
\end{tabular}




\begin{tabular}{|l|l|}
\hline Retrieval algorithms for level2 products & Neural Networks \\
\hline Calibration Systems & LN2 and TIP methods \\
Primary standards & Noise Diodes + ambient Black Body Target \\
Operational standards & $-40^{\circ}$ to $+35^{\circ} \mathrm{C}$ \\
\hline Environmental Operating Range & $0-100 \%$ \\
Temperature & -300 to $3000 \mathrm{~m}$ \\
Relative Humidity & $30 \mathrm{~m} / \mathrm{s} / 60 \mathrm{~m} / \mathrm{s}$ \\
Altitude & $50 \times 28 \times 76 \mathrm{~cm}$ \\
Wind (operational/survival) & $27 \mathrm{~kg}$ \\
\hline Physical Properties & 200 watts typical (Tamb = +25C) 400 watts max at \\
Size (H X W X L) & "cold start" \\
Mass & RS422 $57600 \mathrm{~kb} / \mathrm{s} 8 \mathrm{~N} 1$ \\
\hline Power requirement (100 to 250 VAC / 50 & RS422 $1.2-57600 \mathrm{~kb} / \mathrm{s} 8 \mathrm{~N} 1$ \\
$60 \mathrm{~Hz})$ & $30 \mathrm{~m}$ \\
\hline Data Interface & ASCll CSV (Excel compatible) (comma separated \\
Primary computer port & variables) \\
Auxiliary port & \\
Standard cable length & \\
\hline Data File Formats & \\
\end{tabular}

\subsection{GPS Radiosonde RS-11G}

GPS Radiosonde merupakan instrumen untuk pengukuran berbagai data meteorologi seperti arah dan kecepatan angin, tekanan, temperatur, dan kelembapan relatif untuk udara atas yang dibawa oleh balon udara. Sejalan dengan kenaikan balon udara, radiosonde akan mengukur beberapa variabel data meteorologi seperti kecepatan dan arah angin, tekanan, ketinggian, suhu dan kelembapan relatif. Arah dan kecepatan angin serta tekanan dihitung dari kecepatan dan ketinggian perjalanan balon sonde yang diperoleh dengan teknik pemosisian GPS, sedangkan suhu dan kelembapan relatif diukur dari sensor yang diterbangkan bersama balon.

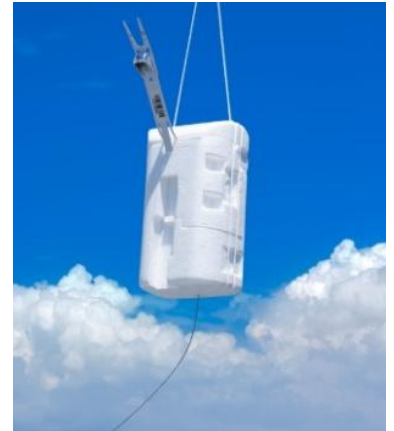

Gambar 2. GPS Radiosonde RS-11G.

Dalam kegiatan IOP ini, radiosonde diterbangkan 4 (empat) kali dalam sehari yaitu pada 00, 06, 12, dan 18 UTC. Spesifikasi radiosonde disajikan pada Tabel 2 .

Tabel 2. Spesifikasi Radiosonde Meisei.

\begin{tabular}{|c|c|c|}
\hline \multirow{4}{*}{ Temperature } & Range & $-90^{\circ} \mathrm{C} \sim+40^{\circ} \mathrm{C}$ \\
\hline & Resolution & $0.1^{\circ} \mathrm{C}$ \\
\hline & Accuracy & $\pm 0.5^{\circ} \mathrm{C} \quad(2 \sigma)$ \\
\hline & Response & $0.5 \mathrm{sec}$ or less $(1,000 \mathrm{hPa}, 6 \mathrm{~m} / \mathrm{s})$ \\
\hline \multirow{4}{*}{ Humidity } & Range & $1 \% \mathrm{RH} \sim 100 \% \mathrm{RH}$ \\
\hline & Resolution & $0.1 \% \mathrm{RH}$ \\
\hline & Accuracy & $\pm 7.0 \% \mathrm{RH}(2 \sigma)$ \\
\hline & Response & $0.5 \mathrm{sec}$. or less $\left(1,000 \mathrm{hPa}, 25^{\circ} \mathrm{C}\right)$ \\
\hline \multirow{3}{*}{ GPM Altitude } & Range & $-200 \mathrm{~m}$ to $40000 \mathrm{~m}$ \\
\hline & Resolution & $0.1 \mathrm{~m}$ \\
\hline & Accuracy & $\pm 5 \mathrm{~m}$ (rms) \\
\hline \multirow{4}{*}{ Pressure } & Range & $1050 \mathrm{hPa}$ to $3 \mathrm{hPa}$ \\
\hline & Resolution & $0.1 \mathrm{hPa}$ \\
\hline & \multirow{2}{*}{ Accuracy } & Surface to $100 \mathrm{hPa}:+/-1 \mathrm{hPa}$ \\
\hline & & $100 \mathrm{hPa}$ to $3 \mathrm{hPa}:+/-0.5 \mathrm{hPa}$ \\
\hline \multirow{2}{*}{ Wind Direction } & Range & Odeg to 360deg \\
\hline & Resolution & $0.1 \mathrm{deg}$ \\
\hline
\end{tabular}




\begin{tabular}{|c|c|c|}
\hline \multirow{3}{*}{ Wind Speed } & Range & $0 \mathrm{~m} / \mathrm{s}$ to $200 \mathrm{~m} / \mathrm{s}$ \\
\hline & Resolution & $0.1 \mathrm{~m} / \mathrm{s}$ \\
\hline & Response & $\pm 0.2 \mathrm{~m} / \mathrm{s}$ (rms) \\
\hline \multirow{6}{*}{ Transmitter } & Center Frequency & $404.5 \mathrm{MHz}$ \\
\hline & Adjusted Frequency Range & $400 \mathrm{MHz}$ to $406 \mathrm{MHz}$ \\
\hline & Occupied Bandwidth & $15 \mathrm{KHz}$ or less \\
\hline & Transmission Power & $100 \mathrm{~mW}$ \\
\hline & Modulation Type & FM \\
\hline & Standard & EN302 054 V1.1.1 \\
\hline \multirow{2}{*}{ Transmission Type } & Type & Digital PCM \\
\hline & Line Speed & $1200 \mathrm{bps}$ \\
\hline Transmission Range & $250 \mathrm{~km}$ or greater & \\
\hline Sounding Cycle & $1 \mathrm{sec}$. or $0.5 \mathrm{sec}$. & \\
\hline \multirow{4}{*}{ Power Source } & Voltage & 3.0VDC \\
\hline & Current & $240 \mathrm{~mA}$ \\
\hline & Type & AA lithium batteries $\times 2$ \\
\hline & Max. Sounding Time & 240mins or more \\
\hline \multirow{4}{*}{ Enhanced Interface } & Standard & ADPort $\times$ 3ch \\
\hline & \multirow{3}{*}{ Optional } & Interface for ECC OzoneSonde \\
\hline & & Interface for Snow White \\
\hline & & AD Port X 8ch Max. for other applications \\
\hline \multirow{2}{*}{ Outlook } & Dimension (WHD) & $98(\mathrm{~W}) \times 155(\mathrm{H}) \times 88(\mathrm{D}) \mathrm{mm}$ \\
\hline & Weight & $150 \mathrm{~g}$ or less \\
\hline
\end{tabular}

\section{METODE}

\subsection{Data dan Metode}

Dalam penelitian ini data yang digunakan adalah data temperatur dan kelembapan relatif udara hasil dari pengukuran radiometer dan radiosonde. hasil pengukuran dari kedua alat ini akan dibandingkan tiap tiap lapisan dimana dibagi menjadi empat lapisan yaitu lapisan permukaan $(1000 \mathrm{~m})$, lapisan bawah $(1500 \mathrm{~m})$, lapisan menengah $(3100 \mathrm{~m})$ dan lapisan atas $(5500 \mathrm{~m})$ pada saat radiosonde dilepaskan. Hasil pengukuran radiometer yang dibandingkan merupakan rata-rata 30 menit sebelum dan setelah balon radiosonde dilepaskan.

\subsection{Korelasi}

Korelasi merupakan istilah yang digunakan untuk mengukur kekuatan hubungan antar variabel. Analisis korelasi adalah cara untuk mengetahui ada atau tidak adanya hubungan antar variabel misalnya hubungan dua variabel (Hasan, 2002).

Korelasi Pearson dipilih karena kelazimannya secara luas dalam penelitian digunakan untuk mengukur sebarapa kuat hubungan linear antara dua variabel (Onwuegbuzie, 2007).

Selain itu dalam hal data yang digunakan dalam penelitian ini berskala interval maka korelasi pearson ini sesuai untuk digunakan. Nilai korelasi sampel (r) diukur dari korelasi
Pearson dengan syarat data berskala interval/rasio yang mana dirumuskan sebagai berikut (Adler \& Parmryd, 2010).

$$
r_{X, Y}=\frac{\sum_{i=1}^{n}\left(x_{i}-\bar{x}\right)\left(y_{i}-\bar{y}\right)}{\sqrt{\sum_{i=1}^{n}\left(x_{i}-\bar{x}\right)^{2} \sum_{i=1}^{n}\left(y_{i}-\bar{y}\right)^{2}}}
$$

atau

$$
r_{X, Y}=\frac{\sum_{i=1}^{n} x_{i} y_{i}-n \bar{x} \bar{y}}{\sqrt{\left[\sum_{i=1}^{n} x_{i}^{2}-n \bar{x}^{2}\right]\left[\sum_{i=1}^{n} y_{i}^{2}-n \bar{y}^{2}\right]}}
$$

Koefisien korelasi menunjukkan kekuatan (strength) hubungan dan arah hubungan dua variabel acak. Nilai koefisien korelasi berkisar antara $-1 \mathrm{~s} . \mathrm{d}+1$.

Korelasi yang erat memiliki koefisien mendekati angka +1 atau -1 , sedangkan korelasi lemah mendekati angka 0 . Jika hubungan antara dua variabel memiliki korelasi -1 atau +1 berarti kedua variabel tersebut memiliki hubungan yang sempurna, sebaliknya jika hubungan antara 2 variabel memiliki korelasi 0 berarti tidak ada hubungan antara kedua variabel tersebut. 
Tabel 3. Tabel Tingkat Keeratan Hubungan.

\begin{tabular}{|c|c|}
\hline $\begin{array}{c}\text { Koefisien } \\
\text { Korelasi }\end{array}$ & $\begin{array}{c}\text { Tingkat Keeratan } \\
\text { Hubungan }\end{array}$ \\
\hline$K K=0$ & Tidak ada korelasi \\
\hline $0<K K \leq 0,20$ & $\begin{array}{c}\text { Korelasi sangat rendah / } \\
\text { lemah sekali }\end{array}$ \\
\hline $0,20<K K \leq 0,40$ & $\begin{array}{c}\text { Korelasi rendah / lemah } \\
\text { tapi pasti }\end{array}$ \\
\hline $0,40<K K \leq 0,70$ & $\begin{array}{c}\text { Korelasi yang cukup } \\
\text { berarti }\end{array}$ \\
\hline $0,70<K K \leq 0,90$ & Korelasi yang tinggi, kuat \\
\hline $0,90<K K<1,00$ & $\begin{array}{c}\text { Korelasi sangat tinggi, } \\
\text { kuat sekali, dapat } \\
\text { diandalkan }\end{array}$ \\
\hline$K K=1$ & Korelasi sempurna \\
\hline
\end{tabular}

\section{HASIL DAN PEMBAHASAN}

Perbandingan hasil pengukuran radiometer dengan radiosonde akan ditunjukan selama kegiatan IOP berlangsung dan salah satu hari saat terjadi kejadian hujan ekstrem yaitu pada tanggal 24 Januari 2016 pukul 18.00 UTC.

\subsection{Perbandingan Hasil Pengukuran Selama Kegiatan IOP}

Secara umum, profil temperatur dan kelembapan relatif yang dihasilkan oleh radiometer dan radiosonde memiliki kemiripan secara visual (disajikan dalam Gambar 3a dan 3b). Kedua data menunjukkan penurunan temperatur seiring dengan bertambahnya ketinggian.

Berbeda dengan profil temperatur, profil kelembapan relatif dari data radiosonde (Gambar 3d) menunjukkan data yang lebih bervariasi dibanding data kelembapan relatif yang dihasilkan radiosonde (Gambar $3 \mathrm{c}$ ).

Metode statistik digunakan untuk melihat seberapa besar variasi data yang dihasilkan dari kedua instrumen. Hasil perbandingan pengukuran temperatur untuk masing-masing ketinggian selama kegiatan IOP ditunjukkan oleh Gambar 4.

Dari gambar tersebut terlihat pada level permukaan atau $1000 \mathrm{~m}$ korelasi antara hasil radiosonde dengan radiometer memiliki hubungan yang menengah dengan nilai korelasinya $r=(0.4528)^{1 / 2}=0.672$, pada level bawah atau $1500 \mathrm{~m}$ nilai korelasi lebih kecil yaitu $r=(0.2561)^{1 / 2}=0.5$, pada level menengah atau $3100 \mathrm{~m}$ nilai korelasi jauh lebih kecil yaitu $\mathrm{r}=(0.0236)^{1 / 2}=0.1$ dan pada level atas atau $5500 \mathrm{~m}$ nilai korelasinya $r=(0.0091)^{1 / 2}=0.09$.

Sementara itu untuk hasil pengukuran kelembapan relatif untuk masing-masing ketinggian selama kegiatan IOP ditunjukkan oleh gambar 5. Dari gambar tersebut terlihat pada level permukaan atau $1000 \mathrm{~m}$ korelasi kelembapan relatif antara hasil radiosonde dengan radiometer memiliki hubungan yang rendah dengan nilai korelasinya $r=(0.0339)^{1 / 2}=$ 0.184 , pada level bawah atau $1500 \mathrm{~m}$ nilai korelasi lebih kecil yaitu $r=(0.0006)^{1 / 2}=0.0245$, pada level menengah atau $3100 \mathrm{~m}$ nilai korelasinya memiliki hubungan yang cukup berarti yaitu $r=(0.2489)^{1 / 2}=0.4989$ dan pada level atas atau $5500 \mathrm{~m}$ nilai korelasinya memiliki hubungan yang tinggi yaitu $r=(0.7324)^{1 / 2}=$ 0.8558 .

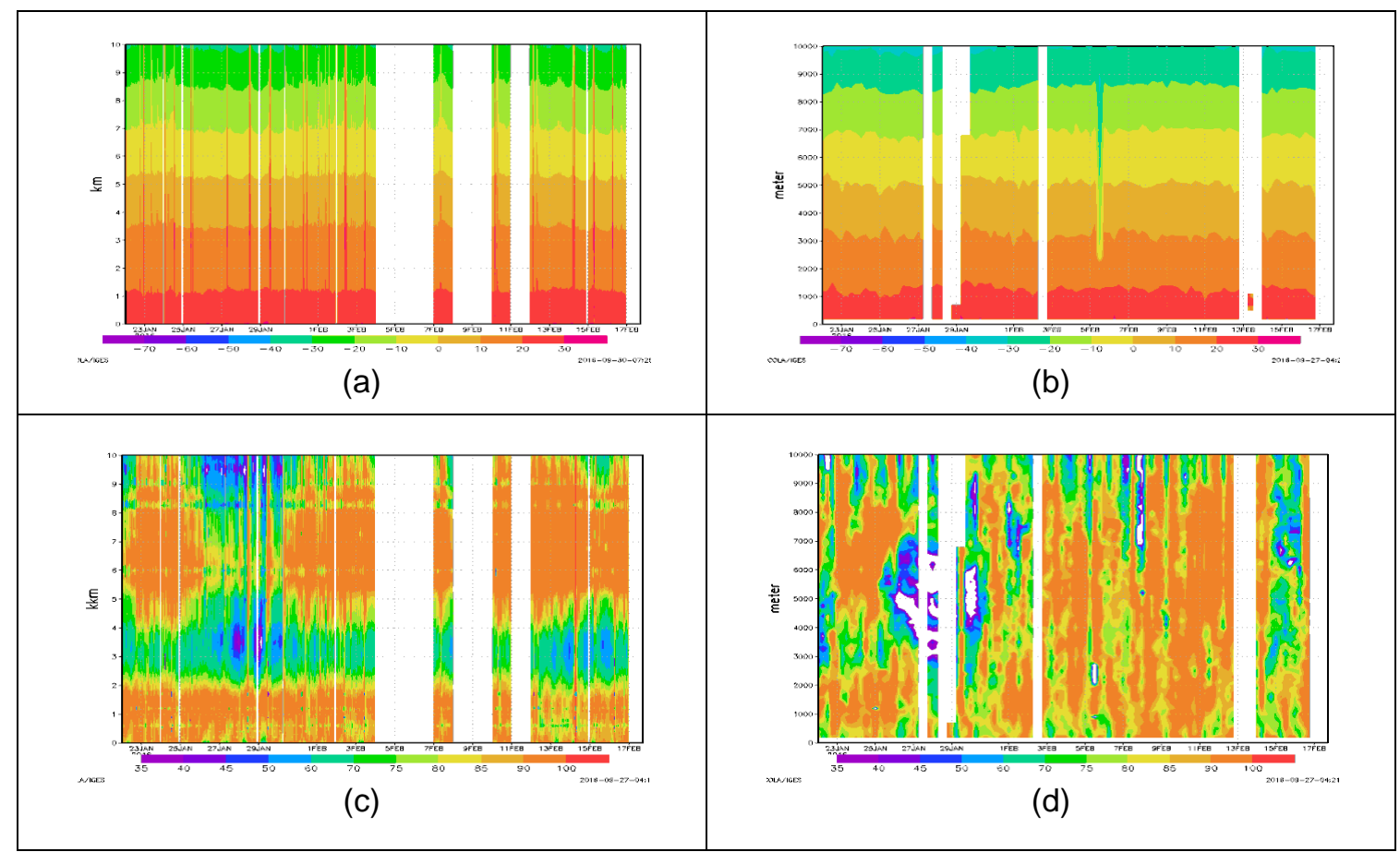

Gambar 3. Profil temperatur dan kelembapan relatif dari Radiometer dan Radiosonde.

(a) Profil temperatur radiometer; (b) Profil temperatur radiosonde; (c) Profil kelembapan relatif radiometer; dan (d) Profil kelembapan relatif radiosonde. 


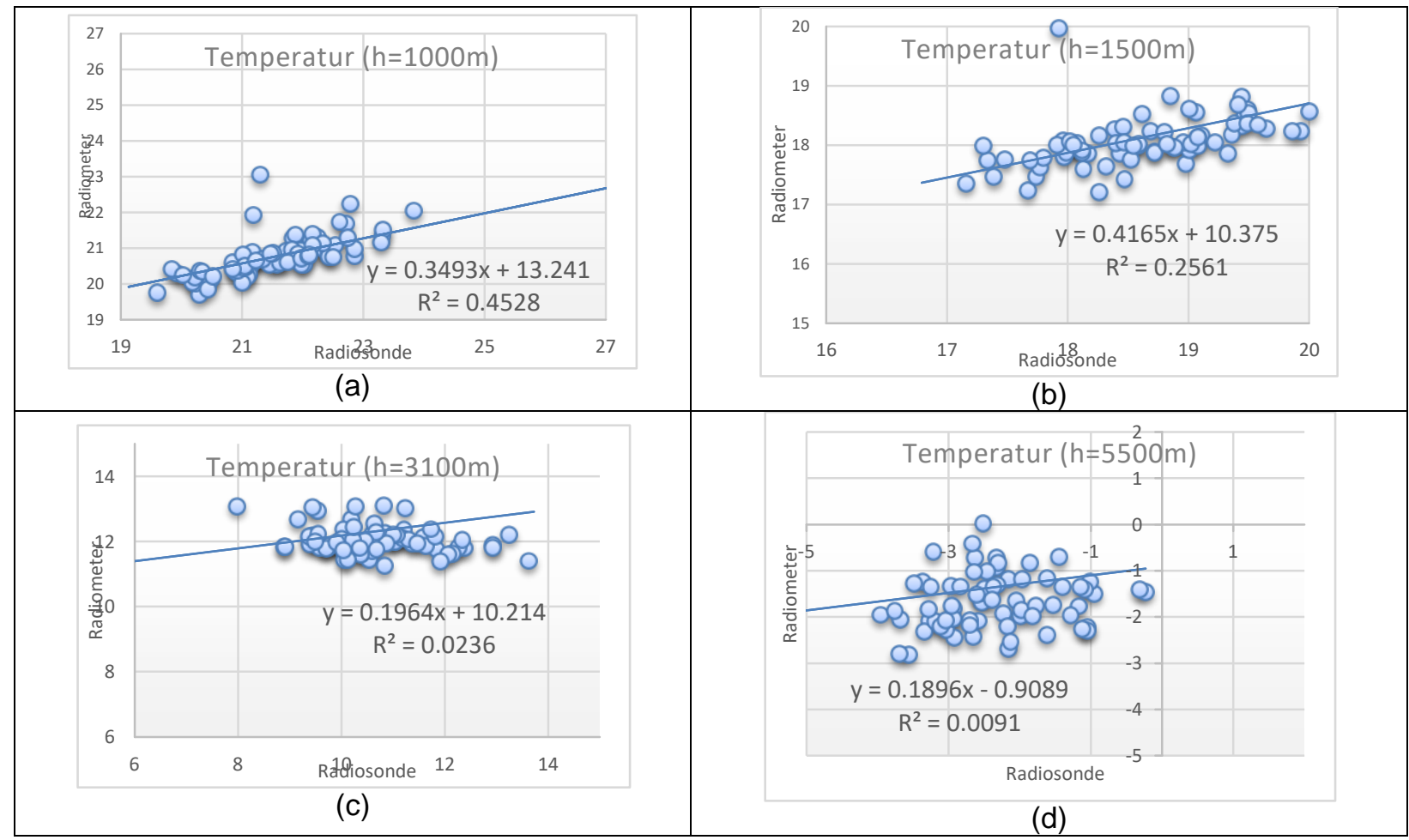

Gambar 4. Scatter Plot pengukuran temperatur radiometer dengan radiosonde

(a) Pada level 1000 m; (b) Pada level 1500 m; (c) Pada level 3100 m; dan (d) Pada level 5500 m.

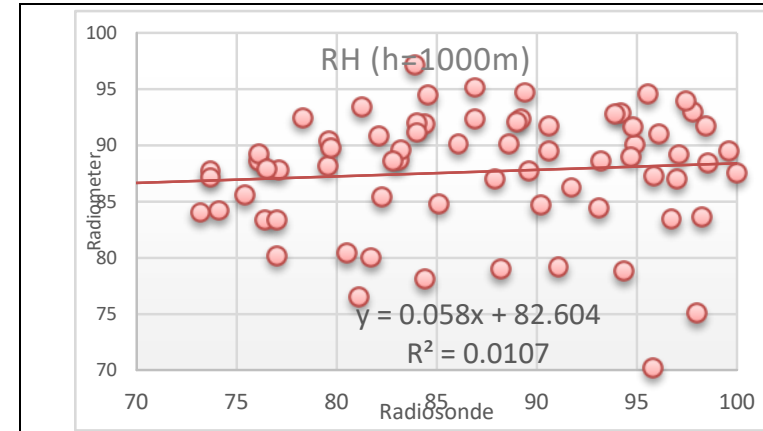

(a)

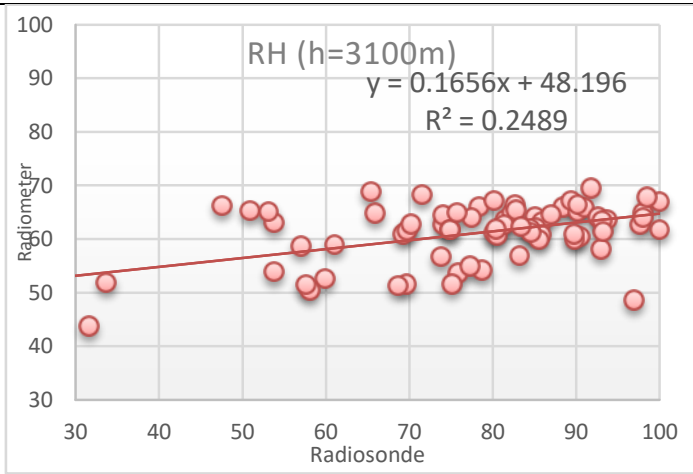

(c)

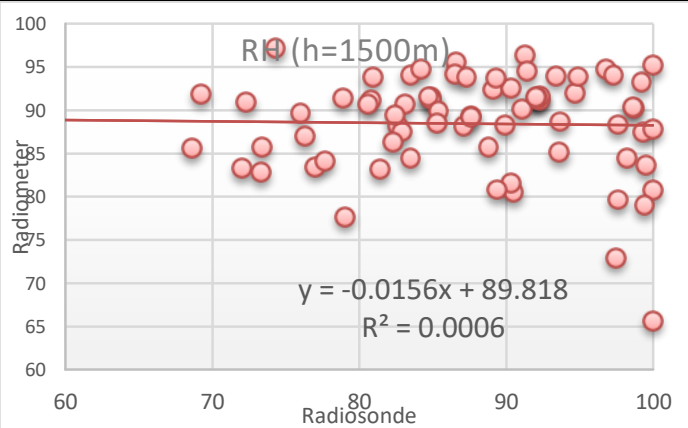

(b)

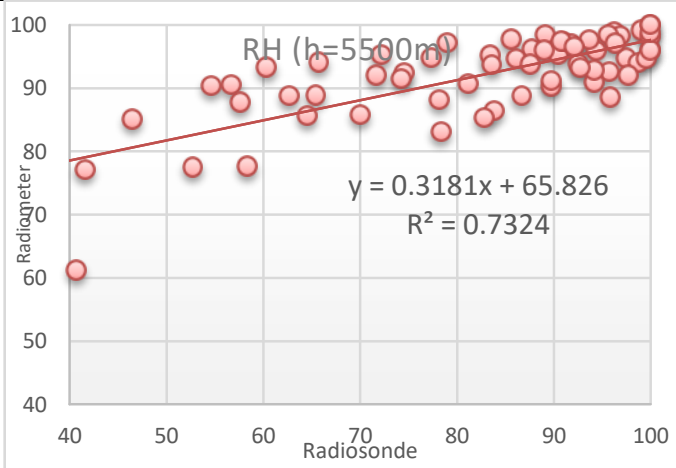

(d)

Gambar 5. Scatter Plot pengukuran kelembapan relatif radiometer dengan radiosonde.

(a) Pada level 1000 m; (b) Pada level 1500 m; (c) Pada level 3100 m; dan (d) Pada level 5500 m.

\subsection{Perbandingan Hasil Pengukuran pada Saat Kejadian Hujan}

Hasil pengukuran radiometer dengan radiosonde akan dibandingkan pada saat kejadian hujan ekstrem yang terjadi pada tanggal 24 Januari pada jam 18.00 UTC. Hasilnya seperti yang ditampilkan pada Gambar
6. Dari gambar tersebut terlihat untuk hasil pengukuran temperatur dari radiometer (garis hijau) mendekati hasil pengukuran temperatur dari radiosonde (garis hitam) pada lapisan bawah (level permukaan hingga level $1500 \mathrm{~m}$ ) dan semakin ke atas hasil dari data radiometer mulai ada kerenggangan dibandingkan data radiosonde. 
Sedangkan untuk pengukuran kelembapan relatif, pada lapisan bawah terlihat data radiometer menyimpang jauh dibandingkan data radiosonde dan semakin ke atas hasilnya lebih mendekati dengan data radiosonde, hal ini menunjukkan hasil yang sama dengan perbandingan pada tiap lapisan seperti yang dijelaskan sebelumnya selama kegiatan IOP.
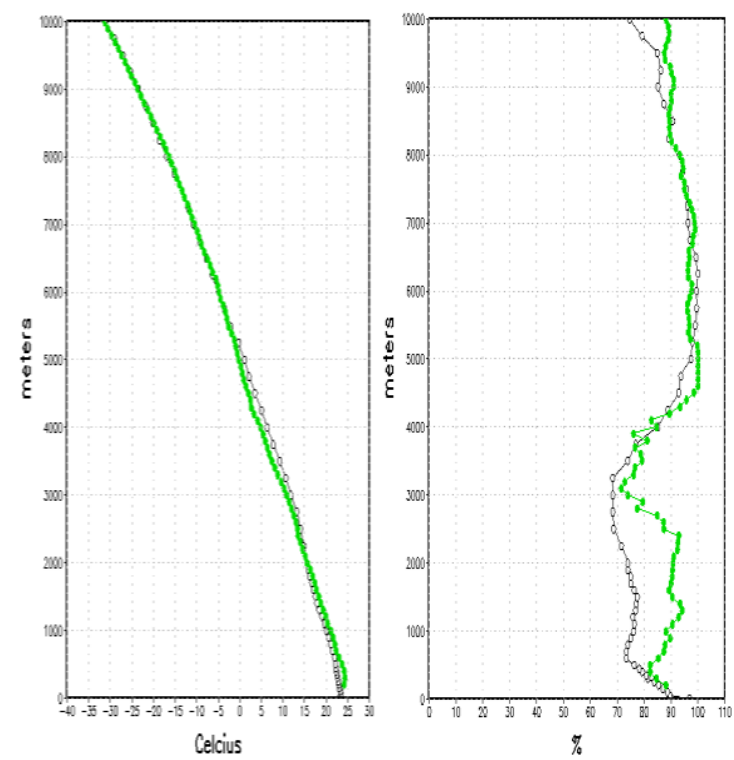

Gambar 6. Plot perbandingan hasil pengukuran parameter temperatur (kiri) dan kelembapan relatif (kanan) antara radiometer (garis hijau) dengan radiosonde (garis hitam) pada tanggal 24 Januari 2016 pukul 18.00 UTC.

\section{KESIMPULAN}

Hasil perbandingan data pengukuran temperatur dan kelembapan relatif dengan alat radiometer dan radiosonde selama kegiatan IOP dari tanggal 18 Januari sampai 16 Februari 2016 secara umum menggambarkan kecocokan data untuk parameter temperatur dan kelembapan relatif.

Setelah membandingkan hasil pengukuran temperatur dan kelembapan relatif dari kedua alat tersebut pada lapisan tertentu, terlihat adanya beberapa data yang mempunyai kecenderungan jauh dan tidak memiliki kedekatan nilai. Untuk pengukuran temperatur, korelasi data semakin kecil di lapisan atas, sebaliknya jika untuk pengukuran kelembapan relatif, korelasi data di lapisan atas lebih tinggi daripada korelasi data di lapisan bawah.

Perbandingan profil atmosfer antara radiometer dan radiosonde pada satu waktu saat kejadian hujan ektrem juga menunjukkan kecocokan untuk kedua data temperatur dan kelembapan relatif, meskipun kecocokan data kelembapan relatif lebih kecil dibandingkan data temperatur.

\section{DAFTAR PUSTAKA}

Adler, J., Parmryd, I. (2010). Quantifying Colocalization by Correlation: The Pearson Correlation Coefficient is Superior to the Mander's Overlap Coefficient. Cytometry Part A, 77a(8), 733-742. doi: 10.1002/Cyto.A.20896

Battaglia, A., Saavedra, P., Rose, T., Simmer, C. (2010). Characterization of Precipitating Cloud by Ground Based Measurements with the Triple Frequency Polarized Microwave Radiometer ADMIRARI. Journal of Applied Meteorology and Climatology, 49(3), 394-414. doi: 10.1175/2009JAMC2340.1

Chan, P.W. (2009). Performance and Application of a Multi-Wavelength, Ground-Based Microwave Radiometer in Intense Convective Weather. Meteorologische Zeitschrift, 18(3), 253-265. doi: 10.1127/0941-2948/2009/0375

Hasan, M.I. (2002). Pokok-Pokok Materi Statistik 1. PT Bumi Aksara, Jakarta.

Hewison, T.J. (2007). 1D-VAR Retrieval of Temperature and Humidity Profiles from a Ground-Based Microwave Radiometer. IEEE Transactions on Geoscience and Remote Sensing, 45(7), 2163-2168. doi: 10.1109/TGRS.2007.898091

lassamen, A., Sauvageot, H., Jeannin, N., Ameur, S. (2009). Distribution of Tropospheric Water Vapor in Clear and Cloudy Conditions from Microwave Radiometric Profiling. Journal of Applied Meteorology and Climatology, 48(3), 600615. doi: 10.1175/2008JAMC1916.1

Madhulatha, A., Rajeevan, M., Ratnam, M.V., Bhate, J., Naidu, C.V. (2013). Nowcasting Severe Convective Activity over Southeast India Using Ground-Based Microwave Radiometer Observations. Journal of Geophysical Reseach, 118(1), 1-13. doi: 10.1029/2012jd018174

Martner, B.E., Wuertz, D.B, Stankov, B.B., Strauch, R.G., Westwater, E.R., Gage, K.S., Ecklund, W.L., Martin, C.L., Dabberdt, W.F. (1993). An Evaluation of Wind Profiler, RASS, and Microwave Radiometer Performance. Bulletin of The American Meteorological Society, 74(4), 599-613. doi: 10.1175/15200477(1993)074<0599:AEOWPR>2.0.CO;2

Mattioli, V., Westwater, E.R, Cimini, D., Gasiewski, A.J., Klein, M., Leuski, V.Y. (2008). Microwave and Millimeter-Wave Radiometric and Radiosonde Observations in an Arctic Environment. Journal of Atmospheric and Oceanic Technology, 25(10), 1768-1777. doi: 10.1175/2008jtecha1078.1 
Montgomery, D.C., Runger, G.C. (2003). Applied Statistics and Probability for Engineers, Third Ed. John Wiley \& Sons. Inc. New York.

Onwuegbuzie, A.J., Daniel, L., Leech, N.L. (2007). Pearson Product-Moment Correlation Coefficient. Encyclopedia of Measurement and Statistics, 2(1), 751756.

Ratnam, M.V., Santhi, Y.D, Rajeevan, M., Rao, S.V.B. (2013). Diurnal Variability of Stability Indices Observed Using Radiosonde Observations over a Tropical
Station: Comparison with Microwave Radiometer Measurements. Atmospheric Research, 124, 21-33. doi: 10.1016/J.Atmosres.2012.12.007

Saavedra, P., Battaglia, A., Simmer, C. (2012). Partitioning of Cloud Water and Rainwater Content by Ground-Based Observations with the Advanced Microwave Radiometer for Rain Identification (ADMIRARI) in Synergy with a Micro Rain Radar. Journal of Geophysical Research, 117, 1-18. doi: 10.1029/2011jd016579 